\title{
Eye Prophylaxis
}

National Cancer Institute

\section{Source}

National Cancer Institute. Eye Prophylaxis. NCI Thesaurus. Code C87074.

The practice of placing antibiotic eye drops or ointment in a neonate's eyes after birth. 